\title{
Impact of Electronic Course Materials on Short Loan Libraries
}

\section{by}

\section{Namrata Banerjee}

Submitted to the School of Information Management,

Victoria University of Wellington

in partial fulfillment of the requirements for the degree of

Master of Information Studies

\section{November 2012}




\section{Table of Contents}

\section{ACKNOWLEDGEMENTS}

\section{ABSTRACT}

1.1 Introduction

1.1 Staffing challenges \& ECMs

1.2. Definition of terms

2. A BRIEF HISTORY OF ECM'S

2.1 Historical Background

2.2 Early Experiments

2.3 Present and Future

3.1 Theoretical Framework

3.2 Delimitations/Limitations

3.3 Research Paradigm

4. LITERATURE REVIEW

4.1 Growth and the changing student population

4.2 New teaching and learning practices 
5.1 Methodology

5.2 Research questions

5.3 Data Collection - Using an online questionnaire

5.4 Research Sample

\section{DATA ANALYSIS AND INTERPRETATION}

6.1 Response Rate

6.2 Data Interpretation

6.2.1 How much of your work is with Electronic Course Materials?

6.2.2 Working as a librarian with Electronic Course Materials requires in-depth training

6.2.4 What are the new skills that you had to learn in order to work with Electronic Course Materials in a satisfactory manner?

6.2.5 What are you faced with most often when working with Electronic Course Materials? Please rank the following items, 1 being the most common issue, 6 being the least common issue.

6.2.6 In the last 2 years instructors requests for readings for availability as Electronic Course Materials have increased over their demand for hard copy availability

6.2.7 Staff were asked if working with ECM's meant they have less contact with students 
7.5 What are the new skills that you had to learn in order to work with Electronic Course Materials in a satisfactory manner?

7.6 What are you faced with most often when working with Electronic Course Materials? Please rank the following items, 1 being the most common issue, 6 being the least common issue.

7.7 In the last 2 years instructors requests for readings for availability as Electronic Course Materials have increased over their demand for hard copy availability

REFERENCES

APPENDICES 


\section{Acknowledgements}

This study would not have been possible without the guidance and assistance of several individuals who in one way or the other have contributed and extended their valuable assistance in the preparation and completion of this study.

First and foremost, I gratefully acknowledge my sincere gratitude to my research supervisor, Mr. Alastair Smith, Senior Lecturer at Victoria University of Wellington, New Zealand, for his efficient guidance through the lengthy path of research with great endurance. His positive feedback, fruitful discussions and valuable suggestions at different stages of this study was a great sense of inspiration.

A very special mention goes to my husband, Mr. Bikram Banerjee for his boundless moral support, encouragement and guidance throughout my MIS course and this study.

I cannot find words to express my deepest gratitude to Mrs. Ursula Loots - my friend, best boss ever, my mentor, and the very reason this study could take place. Without her constant persistence, motivation, guidance, knowledge and push, this project would have remained a dream.

Special thanks go to Mr. John Garraway, Assistant University Librarian at The University of Auckland, for giving me some constructive tips while selecting a title for the project.

Thanks to all my ex-colleagues at The University of Auckland for running a pilot test for me and for giving me their precious feedback.

Thanks to all the survey participants for taking part in the survey.

A special thanks to my mother for her constant support and encouragement.

Last but not the least, the omnipresent God, for answering my prayers for giving me the strength to plod on, despite my constitution wanting to give up and throw in the towel.

\section{Namrata Banerjee}




\begin{abstract}
The advent of Electronic Course Materials (ECM's) services in academic libraries has had a remarkable impact on academic libraries, since they provide new prospects for libraries, library staff and various new methods for accessing library services for its users. With the challenge for the librarians growing in multiple scope due to Information Communication Technologies (ICT) applications. This study will look at how and to what degree has the implementation of ECM's made an impact on staff's work in academic libraries.
\end{abstract}

\title{
Purpose
}

The purpose of this proposed research study is to explore how Electronic Course Materials (ECM's) have affected the work of librarians in academic short loan collection in New Zealand tertiary institutions.

\section{Design/methodology/approach}

This study adopted a mixed-method approach and utilized both qualitative and quantitative research methods. An online survey was applied for this study where questionnaires were sent to the respondents via a URL.

\section{Findings}

This study sought to find out whether ECM's have made any impact on staff's work. The resulted indicated that ECM's setting is in a state of transformation. This transformation has enabled the library staff to learn new technology to work with ECM's effectively and this has encouraged them to learn new skills in order to achieve the required results.

\section{Originality/Value}

There is very limited research in this area; this makes it beneficial to investigate this area. Research findings will prove beneficial to the librarians as they could look at the research findings and compare their services with the result. Academic libraries could use new technologies to improve their services, which may help them to support the teaching and learning process.

\section{Keywords: Electronic Course Materials, Electronic Reserves, Short Loan Collection.}




\section{Background to the study}

\subsection{Introduction}

Numerous academic libraries are facing the pressure of increasing library usage and reduced budgets. To cope with this pressure, the academic libraries have made changes to the way study materials are delivered to students. In most cases, recommended reading materials for students are in limited supply, expensive to buy, are in high demand and there are too many students who have to be provided with sufficient access to these materials.

A survey of university libraries revealed that changes in teaching methods have put an additional strain on library resources. Project work, for example, demands more student-centered work and, thus, impacts on demand (Sumsion, 1994).

In a survey Cockrill (1997) points out that many libraries reported that since some recommended / prescribed print resources were in high demand, and were only available over a short time period, it was difficult for them to provide materials efficiently and in adequate amounts for the growing amount of students. "Balancing the requirements of those with opposing needs can be difficult" (Dugdale, 1998).

Traditionally, the concern of too many students chasing after insufficient books has been addressed by academic institutions to a certain extent. For example, by making multiple photocopies of an article or chapter from a book, or removing a book from the generic collection and by placing it in a short loan collection for a limited period of time, or even by restricting it to library use only. Several universities offering short courses per semester, e.g. Summer School or students appearing for examinations have made a bigger impact upon the trend towards high demand periods for some recommended items, thus creating short but demanding periods for some items.

"Recently, many libraries have used systems to make their course reserves available to patrons in electronic format" (Rojeski 2012). Some well accepted form of providing access to course 
materials is through Learning Management System (LMS), i.e. Blackboard or Moodle, which facilitates learning amongst students.

Electronic Course Materials (ECMs) play an important role in smooth functioning of a library by increasing access to what otherwise would have been an inadequate print resource. At the same time, ECMs facilitate in cutting staff time at the lending desk, as it is not required of staff to spend much time in issuing items to users, thus, their valuable time can be used elsewhere, and this issue is discussed at length below. ECMs could be considered a possible alternative to purchasing books in some cases, e.g. faculties end up buying multiple copies for just one prescribed chapter and, if that prescribed chapter is made available online for all students, libraries could end up saving that fund.

\subsection{Staffing challenges \& ECMs}

In most cases, recommended reading materials for students are limited, expensive to buy, are in high demand and/or there are too many students who have to be provided with adequate access to these materials.

With the advent of improved network technologies and software solutions, and also driven by increased user demand for an uninterrupted access to high demand materials, ECMs projects have proliferated throughout the decade as Secker (2004) pointed out. The method of delivering course materials to students has changed considerably with the superior technology and as stated by Secker (2004) e-learning has also impacted on the working practices of librarians.

By the end of the 20th century, large number of academic libraries provided electronic course materials services (Kristof, 1999) in conjunction with reserves for traditional print collections. As Laskowski, et al (2003) points out "there are plenty of assumptions and eagerness about the potential staffing benefits", such as saving staff time which is the prime amongst them. There are doubts looming about the impacts of the implementing of a ECMs system on staff, e.g. staff training, space allotment, and other daily responsibilities. 


\subsection{Definition of terms}

\section{Electronic Course Materials (ECMs) service:}

(Kupersmith, 2002) defines ECM's as:

"The actual reserve materials are stored in an electronic format in text or graphic images, for access retrieval viewing, downloading, or printing by students. Depending on the system design, this access may take place through remote network or dial up connections as well as in the library. The reserve materials may be in a format of books, photocopies of chapters or journal articles, audio-visual items or any other notes provided by faculty. The library may also place on reserve other types of material such as archival collections of dissertations or yearbooks that are vulnerable to theft or deterioration".

As also defined by Chrzastowski (2002), it means "Reserves" holding a set group of materials for use by a set group of people, usually, students. ECM's basically replicate print reserves in an online format for student's convenience to access to digital materials. ECM's provide a centralized service for the submission, processing, production and copyright management of all reading materials from prescribed texts, journals and these are made online in accordance to the Copyright Act. Submitted materials are made available via a library's catalogue, which are accessible continuously by students, even remotely.

In layman terms, it means that 'the world wide web provides the ability to host a high quality multimedia learning materials such as text, pictures, videos and audio'. (Amarathunga, 2009).

Basically there are two main types:

- Printed materials such as chapters or extracts from books, journal articles or conference proceedings which have been scanned into a digital format. The print materials are scanned into PDF format for viewing using Adobe Acrobat Reader.

- Existing electronic documents such as full-text database articles, electronic journals, and electronic books. In most cases, if a link already exists, a stable link to the electronic document is created. However, requests to link to such items must come via the ECMs 
service to ensure that copyright and license restrictions are observed and that the URL created is persistent.

\section{Academic Libraries}

An academic library plays a crucial role in the context of a new learning paradigm. It is an integral part of university's educational system. The aims and content of an academic curriculum operates in the educational setting of an academic library. Alternatively it means that an academic library is influenced by the content of the institution's curriculum. (Juceviciene, P. and Tautkeviciene, G, 2003).

- It is a fundamental part of university's educational system

- It has to interact with all the educational environments of academic study programmes

- Its regular clients (students, teachers, researchers, administration staff) interact with each other

- The selectivity of academic library learning environments depends on the type of clients and the educational environment of study programme which is significant for students in particular.

A tab (2003) defines the academic library in simpler terms as:

It is an entity in a post-secondary institution that provides the following:

- An organized collection of printed or other materials, or a combination thereof.

- Staff trained to provide and interpret such materials as required to meet the informational, cultural, recreational, or educational needs of a client.

- An established schedule in which services of the staff are available to clientele.

It also includes libraries that are part of learning resource centers. (Tabs, 2003)

\section{Short Loan Collection:}

Short Loan collection consists of prescribed and recommended materials, as requested by teaching staff. Short loan provides controlled access to materials in high demand. It is intended to be confined

To material that is high in demand and integral to the course for which it has been provided. 
Academic libraries introduced short loan collections to increase access to high-demand stock by 'rationing' the length of loan period (Dugdale, 1999) 


\section{A brief history of ECM's}

\subsection{Historical Background}

ECM services have been provided by many academic institutions to support faculty and students alike for some time now. "Electronic reserves has existed as a library service for barely ten years, yet its history, however brief, is important as an indicator of the direction being taken by the profession of Librarianship as a whole" (Austin, 2001).

Although, ECM's have a brief history, the service deserves a mention in this study and is worthy of being examined not only as a 'development of a service, but as a reflection on the journey that is being made by the profession of Librarianship as a whole' (Austin, 2001).

Miller (2000) states that 'in late 1970's and early 1980's, very little ground-breaking changes were seen'. Same can be said of late 80's and early 90's with regards to ECM services. There was however, a good amount of discussion in the literature only around 1993 on "automating reserves", i.e. streamlining the processing of course materials through automation or the development of "stand alone" automated reserve databases and their integration into Integrated Library Systems (ILS). (Austin, 2001). Mention of virtual libraries or digital libraries were common back then and they were mentioned frequently in the literature from mid - 1980's onwards, and 'the concept of ECM's appeared to have coalesced' (Austin, 2001). Earlier, only a few selected print materials largely from little used library collections were focused upon for digitization, since digitization was mainly seen as an archival tool, but there was a "fear of approaching the digital use of copyrighted materials". (Butler, 1996). New focus on the course reserves that were highest in demand was the changing face of ECM's.

\subsection{Early Experiments}

In July 1994, a forum on ECM's was sponsored by the Association of Research Libraries (ARL) and the National Association of College Stores (NACS) was held in Denver, USA. There were three representatives "often considered as pioneer of electronic reserves" (Soete, 1996) present there at the conference. These were Colorado State University, San Diego State University and Duke University, which at that time were the only three universities, which offered the services to their constituencies on any sort of systematic basis. It was interesting to see the different approaches these universities took both philosophical and methodological in providing the ECM Service. The table is given below on the various types of formats these Universities worked on. 


\begin{tabular}{|c|c|c|c|}
\hline $\begin{array}{l}\text { Types of } \\
\text { Reserve }\end{array}$ & Duke University & $\begin{array}{l}\text { San Diego State } \\
\text { University }\end{array}$ & $\begin{array}{l}\text { Colorado State } \\
\text { University }\end{array}$ \\
\hline $\begin{array}{l}\text { Types of items } \\
\text { on Reserve }\end{array}$ & $\begin{array}{c}\text { Notes, problem sets; } \\
\text { journal articles; book } \\
\text { chapters }\end{array}$ & $\begin{array}{l}\text { Notes, problems, exams } \\
\text { solutions; journal } \\
\text { articles; book chapters }\end{array}$ & $\begin{array}{c}\text { Exams, class papers, } \\
\text { Faculty papers }\end{array}$ \\
\hline $\begin{array}{l}\text { Type of } \\
\text { system }\end{array}$ & $\begin{array}{l}\text { Optical jukebox built in } \\
\text { collaboration with Xerox } \\
\text { Corp. }\end{array}$ & $\begin{array}{l}\text { "Home built" network } \\
\text { within the library }\end{array}$ & $\begin{array}{l}\text { Gopher based; } \\
\text { "home" } \\
\text { Programming }\end{array}$ \\
\hline $\begin{array}{l}\text { Storage } \\
\text { Format }\end{array}$ & $\begin{array}{l}\text { RDO (Raster Display } \\
\text { Object) graphic Images }\end{array}$ & $\begin{array}{l}\text { Bit-mapped graphic } \\
\text { images }\end{array}$ & Text files \\
\hline Access Points & $\begin{array}{c}3 \text { stations in library (2 West } \\
\text { campus; } 1 \text { east campus) }\end{array}$ & $\begin{array}{c}6 \text { workstations within } \\
\text { library }\end{array}$ & $\begin{array}{l}\text { On internet with } \\
\text { unrestricted use }\end{array}$ \\
\hline $\begin{array}{l}\text { Charges for } \\
\text { Service }\end{array}$ & No Charge & $\begin{array}{l}\text { Free viewing } 10 \text { cents } \\
\text { page charge for printing }\end{array}$ & No Charge \\
\hline
\end{tabular}

Table 1: Sources: Data from Forum (1994); Bosseau (1991); Delaney and Smith (1993); Delaney (1994); Clifton (1996)

In a survey sponsored by ARL (Kristof, 1999) states that between 1995 and 1999, 25 other member libraries began to offer ECM service and many others launched pilot projects. Incidentally, this was also the time when the World Wide Web surfaced as a vital information tool, and which was also contributed to the emergence of ECM.

\subsection{Present and Future}

As Melamaut (2000) stated that 'academic libraries future included ECM's'. This is indeed very true of academic libraries in general. He goes on to point out that 'the convenience for students and academics is too great to ignore', this it is apparent given the interest of academic libraries providing distance education, and also, the technology which has made ECM's possible and the Copyright issues which are 
dealt by the librarians will continue to develop. As George Soete predicted way back in 1996, that "no single standard is likely to emerge soon" and "there will be a tremendous diversity of approaches" has not only proven to be precise but it also very true as new emerging trends continues to develop and grow.

ECM's have become easier to use for both staff and students, and technologically, the service will only go on to become faster to process and access, with Copyright issues still looming unresolved. 


\section{Research Objectives}

Even though there is a lot of literature available on ECMs and the use of short loan libraries, unfortunately not much literature has been published (past or present) on the impact ECMs have on short loan libraries. This makes it difficult to understand the past trend, hence this study.

The purpose of this proposed research study is to investigate the affect of ECMs on academic library short loan services in New Zealand tertiary institutions and also on staff's work. To date, as mentioned above, limited research has been done that focuses on this area, making it beneficial and valuable to investigate this area.

The research findings will be beneficial to librarians as they could benchmark their ECMs services and also learn how ECM's affect staff work, since the emphasis of the study is on the latter. Academic libraries could execute new technologies to improve their services, which in turn will help them to support the all important teaching and learning process.

Thus, the research will be a useful and helpful benchmarking tool against which other tertiary institutions can measure their electronic course materials services.

\subsection{Theoretical Framework}

The Task/Technology Fit (TTF) theory has been chosen for this study. This model is realistic for the study because ECMs make complete use of technology - for example: Scanning, Image manipulation, PDF processing. But what is Task/technology fit?

The TTF theory implies that Information Technology (IT) is more likely to have a positive impact on any individual performance if IT fits the tasks the user is to perform. "TTF fit theories are theories that argues that, use of a technology may result in different outcomes depending upon its configuration and the task for which it is used." (Goodhue \& Thompson, 1995). 
The TTF model is chosen for this research because ECM services uses the technology which fits the tasks the user wants to perform, a technology which provides a synchronized, remote and online access to course materials to patrons.

For easy comprehension, the model's characteristics can be broken into two parts:

\section{- Characteristics of Task \& Technology}

\section{ECMs:}

- provide multiple accesses to multiple students at the same time

- Allow students to access course materials online without physically being present in a library

- Ease of access and instant availability of full-text access allows students a convenient access and this makes ECM's very popular (Moyo, 2004).

- Utilization and performance:

(a) The points mentioned above affect the performance and the utilization of the system.

The objective of this research is to find out if the ECMs services have made any impact in short loan library services across New Zealand universities. Therefore, the TTF model is adopted for this research to see if the task and technology characteristics are a good match. Also, research on acceptance of ECM service by academic staff was earlier conducted by Upeksha Amarathunga in the year 2009; therefore, this particular study will concentrate on the acceptance of ECM service by the library staff in an academic setting in New Zealand tertiary institutions.

The TTF model will also prove to be helpful in this research, as it will be able to determine the level of impact the ECMs service have made to its users in short loan libraries in New Zealand tertiary institutions. The attitude of the end-users of the technology will be positively affected, if the new technology has made any impact to the service delivery of its users. 


\subsection{Delimitations/Limitations Delimitations:}

- This research is restricted only to librarians and Short Loan library managers employed in New Zealand tertiary institutions

- This research is being conducted from India, although the researcher did not face any specific issues that this caused, but considering the distance; the results may not be able to provide indepth interpretations of the findings.

\section{Limitations:}

- Time and distance limitation bars the researcher from doing interviews, even though modern day technologies such as Skype do offer possibilities for interviews.

- Limitations to the amount of free customer support a researcher may obtain while using survey software's, even though customer support may be available for minor technical issues and customer queries which is only to a certain limit.

- Limited to electronic format questionnaires, due to distance of researcher from New Zealand, results may not be able to provide in-depth interpretations.

- Due to location, resources and time limitations, questionnaires were sent out via a URL link to various library staff in electronic format.

\subsection{Research Paradigm}

The researcher acknowledges the fact that all the participants involved in this study have brought their own unique interpretation of the situation and, 'the researcher must be open to the attitudes and values of the participants' (Mackenzie \& Knipe, 2006). Therefore, this study has chosen interpretivist paradigm. The interpretivist researcher tends to rely upon the "participants' views of the situation being studied" (Creswell, 2003, p.8) and recognises the impact on the research of their own background and experiences.

Although, one of the criticisms of interpretivism is that it does not allow generalisations because it encourages the study of a small number of cases that do not apply to the whole population (Hammersley, n.d.). However, others have argued that the facts and effort involved in interpretive inquiry allows researchers to gain insight into particular events as well as a broad range of view which would not have come out without an analysis (Macdonald, Kirk, Metzler, Nigles, Schempp \& Wright, 2000; McMurray, Pace \& Scott, 2004). This approach was 
appropriate for this research since it assisted the researcher to understand participant's perception on the given topic which was controlled by their beliefs. One of the objectives of this study is to determine the impact ECM's have made on academic library and on staff's work. Thus, in this project, the human behaviour towards the impact ECM's have made on academic institutions and staff will be studied. 


\section{Literature Review}

ECMs make prescribed and recommended journal articles, book chapters, book extracts, conference papers, parliamentary materials available online for students course work for all subject areas. Alternatively, 'it is also known as short loan or course reserves' (Rosedale, 2002). Electronic course materials derive its name from the print reserve services offered by academic libraries, since short loan provides physical access to course materials in high demand; ECM's provide electronic access to course materials.

Electronic Reserve or ECM's (E/R or E- reserves) or ECMs services are not new services, as Austin, 2001 points out ECM's have existed in the literature for more than 8 years. (Kristof, 1999). Chrzastowski, 2001 stated that that "they are not new services but just a new way to conduct an existing service". Libraries have achieved this system upgrade by either purchasing commercial software to manage these services or by simply developing homegrown programs.

\subsection{Growth and the changing student population}

There has been a significant growth in student numbers since the turn of the century, and this in turn has greatly increased the usage of academic libraries. According to a survey conducted in the United Kingdom, it was reported that student numbers have more than doubled over the last 20 years. The composition of the student population has also changed noticeably (Davies, 1997), with new composition patterns demanding career direction changes, which may involve recurring phases of retraining, achieving new skills and returning to education to upgrade themselves in some cases. One factor that contributes to the fact is the change in employment patterns (Handy, 1994). This resulted in a growth in university student numbers impacting library services. There are numerous literatures that point out the major concerns about the brisk growth in university student numbers (Dugdale, 1998, and Feather \& Marriott, 1993).

In addition to the growth in student numbers, there has also been funding losses in real terms across the university sector (Tysome, 1996) an issue facing many academic libraries. This concern has been combined (in some universities) with cuts in library expenditure as a 
percentage of total university expenditure (Sumison, 1997, Secker, 2001). Unfortunately, this indicates that fewer library books may be bought per student.

Even the libraries which did not have to put up with large funding losses, have found it essential to think of new means for addressing the issue of increasing availability of limited print copies of core texts.

\subsection{New teaching and learning practices}

Due to changes and growth in recent technologies, new teaching and learning practices are emerging. The phenomenal advancement of technology is "providing students with a convenient access to prescribed resources is something that librarians, teaching faculty and others involved have to work in tandem to ensure that students not only have access, but are provided with opportunities to grow as independent lifelong learners”. Magusin \& Johnson (2004).

These days, students first look up online for their information, so having an online point of access is crucial as Hoppenfeld and Arant-Kaspar, (2010) note. On the other hand, keeping this trend in mind, academic staff these days have several modes of distributing course readings to their students. Opposed to the old course reading packs Clumper et al. (2011) presented their efforts to embed the course reserves at Northern Michigan University through their Moodle course management system. Alternatively, Goodson and Frederikson (2011) explore ways in which libraries can benefit from online Course Management software to boost their electronic services, and to make the electronic collections more accessible to patrons. Talis Aspire campus is a new and exciting purpose built reading list software existing in the cloud which been on the market since 2009. Talis Aspire matches the workflow of all the stakeholders - academics, students and libraries. Due to emphasis on open, distance, student-centered and active learning with reduced staff/student contact hours, library use has multiplied. Cockrill (1997) did a survey which also revealed that libraries reported high demand for some texts over short period of time, making it very difficult for them to provide materials efficiently and in adequate amount. Feather \& Marriott (1993) pointed out twenty years ago that the concerns about the problems caused by too many students chasing too few books were already being voiced several years ago. 


\subsection{Print Short Loan Collections - A solution}

So how do libraries cope with this issue? One means of addressing the issue of too many students pursuing fewer core texts is the implementation of an efficient loan period 'rationing' tool. This is known as the Short Loan/Reserve/High Use Collection in academic libraries. A Short Loan Collection increases the accessibility of recommended texts to several users over a period of time. The system was created in response to demands from academic staff. Balancing the needs of those with different requirements can be tricky. Short loan caters to an instant response to the user's needs. According to Dugdale (1998) 'collections are generally built on a flexible approach reflecting the particular ethos' For example, removing books from the main collection to the short loan collection may assist some students, who are required to read one or two chapters of the recommended readings, but not for others who are required to read the whole book or a major chunk of it.

However, with more books moving into a short loan collection, library enlargement may benefit students further. In fact, volunteered comments on a questionnaire in a survey suggested that:

- Short loan area must be increased

- Library should accommodate more books

- There should be a bigger selection of texts

The students felt that due to continuous class assessments, there was an increase in demand for course books, and a bigger short loan area will be able to accommodate more books.

\subsection{Electronic Course Materials in the Teaching Environment}

Many issues, which traditional print short loan cannot manage, may be successfully addressed by the introduction of an electronic reserve or electronic resource base. As explained by McCaslin (2008, p.337) "With advances in technology, by providing course material electronically, multiple students can access the same information simultaneously, and this has greatly increased students' access to information". Also, as argued by Dugdale (1998) an electronic reserve collection's management control mechanism can help automate the flow of documents in and out of the system with more ease compared to the manually operated print short loan collection system. This can also assist in making the materials accessible for a larger group of users during 
peak time. Secker (2001, p.35) argues that many issues related to print Short Loan collection can be successfully addressed by introducing an electronic resource base for example ECMs..

"Method of delivery and learner support has evolved in response to advances in information and communication technologies" according to Magusin \& Johnson (2004). Many universities have taken a variety of approaches towards providing access to electronic course materials. Some universities have even built their own in-house electronic reserve system (Secker, 2001). There are a growing number of universities that provide access to electronic course materials, and this has been running for a few years (Secker, 2001). There are quite a few combinations of approaches possible for example, linking electronic course materials to WebCT, a Virtual Learning Environment (VLE) or Learning Management System (LMS) such as Blackboard or the Circulation reserve module (Secker, 2001). This method is discussed at length below.

\subsection{Virtual Learning Environment (VLE)}

In layman's terms, a VLE is a software tool which amalgamates a variety of resources and which also enables learners and staff to jointly interact online. At the same time it makes the content delivery and tracking of it possible (Becta, 2004).

There are several known benefits of VLEs on teaching and learning. Some important core points are mentioned below:

- Improved teaching and learning

- Teachers can share and work together with other teachers

- Controlled access to curriculum resources

- Online assessment and marking.

Interest in digitizing course materials has increased in tandem with the growing prevalence of VLEs such as Blackboard, Moodle or WebCT.

\subsection{Electronic Course Materials - Advantages}

There are various advantages associated with electronic course materials. They increase the accessibility by providing multiple-user, multiple locations, perpetual and remote access. 'Since 
materials can be accessed from a remote distance, it increases the level of accessibility' (Konicek, Hyzny and Allegra, 2003). Groenewegen (1998) points out that at Monash University (Australia), about 25\% of the students have no direct access to a physical library building at all. Delivery of library materials to students via traditional mode (mail and courier) is quite expensive and labour intensive. Electronic course materials thus, turn out to be the only feasible option.

In addition to accessibility, other advantages of electronic course materials are listed below:

- Use of SFX links to reduce chances of broken links, results in better accessibility (Cheung \& Patrick, 2007)

- Improved availability to non-traditional students, who are unable to physically get to the library during opening hours, due to their distant off-campus location (Secker, 2001)

- Resources are protected from theft and wear and tear (Shapiro, 1995)

- Users can access large numbers of items even if a library may have a borrowing limit (Dugdale, 1998)

- Ability to print and download for longer access (Dugdale, 1998)

- Storage space is vastly increased (Dugdale, 1999)

- Saves staff time since they are not required to issue items to users, hence, their time can be used elsewhere (Dugdale, 1998)

"An evaluation indicated that the assignment work by students using electronic reserve was far better and of a much higher standard than previous years using print collections" (Dugdale, 1998).

\subsection{Copyright - A Challenge}

Electronic course materials have the same legal issues regarding copyright as print materials Driscoll, (2003). As Driscoll (2003) points out "Copyright is determined by considering four factors, which are: purpose of use, nature of work, amount and substantiality of materials from 
original work and effect of use on the value of the protected work". (Fair use is opposed to the doctrine of fair dealing used in other countries in the world, such as New Zealand. Fair use is less restrictive than fair dealing) (Secker, 2010) Copyright issues are a big challenge that librarians have to deal with (Driscoll, 2003).

While many issues surrounding library administration of digital contents have been resolved, other issues still loom large over academic libraries. Bridges (2007) notes that practices 'differ widely and are influenced by institutional organizational structures, information, technology infrastructure, manpower, demand, and the copyright law'.

New Zealand universities negotiate copyright licenses with Copyright Licensing Ltd (CLL) which allows staff copying the following extracts from books, periodicals, and journals:

- Up to $10 \%$ or one chapter of a work, whichever is the larger

- Up to 15 pages of a single work in a collection of works even if the work is published separately

- Up to one article from a periodical publication. Additional articles may be copied if they are on the same subject.

"Exceptions provided for certain educational institutions (schools, universities, and non-profit training establishments) allow one copy of the whole work/part work to be made for instructional purpose and for classroom use. This also includes digital copying” (Copyright Act of 1994)

Ferullo (2002) argues that library users have changed with time. She evaluated the copyright issues related to providing online access to electronic course materials with the recent changes and development in technology. Users want instant and flawless access to all types of study materials both on campus and remotely. She states that though copyright laws limit providing flawless online access to full-text material, the copyright law has opportunity and flexibility because of fair use or fair dealing exception.

Different institutions pursue different policies, but whatever policy is adopted, it is crucial to be consistent in its implementation, and the policy must be reviewed with the institution's legal counsel. 


\subsection{Technology \& role of the librarians}

With the advancement of technology, librarians play a vital role in meeting the expectation. "With the growing technology, librarians need to be able to confront the explosion of electronic resources" as stated by Duncan (2011, p.6). ECM's involve a higher level of skills to manage than traditional formats.

This also requires an "efficient and effective communication between libraries' various departments, since there are so many different staff members involved in selecting, managing, and acquiring the resources" (Duncan, 2011).

Electronic Course Materials services provide opportunities for librarians to become proactive by adopting crucial roles in shaping their institutions.

Dugdale (1999) argues an electronic reserve can be used more creatively than merely as a 'housekeeping' tool. She goes on to suggest that this can only be achieved if librarians adopt a new role and split responsibilities of teaching and learning strategies.

ECM's are perceived as visibly central resources, which reach out across networks to each part of an institution. They are expensive services which are required to manage and run efficiently (Dugdale, 1999). Librarians meet the criteria perfectly, since they are trained to recognize their user's information requirements, they can "add value" to information for the users while assisting in the reduction of user ambiguity in response to the access and use of new information formats (Rice-Lively and Racine, 1997).

Moyo (2004) stated that "with changing technology, library work is also beginning to change. As a result, librarians have a new role in facilitating users with a smooth access and navigation of electronic resources". To carry it out successfully, the librarians must form new relationships within the institutions, and therefore, they should be well organised to meet the new challenges. "Upon request by faculty instructors, librarians do provide additional support for Blackboard courses, by providing links to key databases, creating tutorials or by developing course guides for patrons use" as pointed by Goodson \& Fredericksen (2011). 
Creth (1996) states that past relationships between IT and librarians have been characterized by 'unease, caution, lack of knowledge, misunderstanding, and mistrust on occasion'. An electronic course materials service demands sufficient technological know-how. Efficient and reliable service can only be offered when librarians share a close association with IT supports department.

Librarians must be proactive in explaining the teaching and learning potential of systems and by helping academics. They actually help in shouldering responsibilities. Goodson \& Frederickson (2011) observe that librarians play a vital role by "providing additional support for Blackboard courses, (for example: by proving links to resources, creating tutorials on particular research tasks to name a few).

It is however, clear that all groups of staff, and areas of expertise need to work together as a team in order to deliver teaching excellence. Librarians lack academics' depth of subject knowledge and teaching experience and digital services on the other hand, are demanding upon librarians. This however opens up opportunities for central information management that librarians are best able to provide and if this does not happen, electronic course materials might become a costly and a separate entity in an institution, and will never become anything more than an under-used support service.

The literature revealed that ECM services are not new and yet there were not too many research materials available on how ECM's affect the work of librarians in an academic library setting. Following are the issues that were identified during this study which will be investigated in this study.

$\checkmark$ Though, there has been a considerable increase in student population, funding losses across the university sector remains a concern. With a boost in population, universities across the world are facing a concern of too many students chasing texts which are fewer in numbers and this lead to implementation of a loan system i.e. Short Loan Collection, a collection of high demand and prescribed texts. 
$\checkmark$ As technology progressed, ECM's were introduced to cope with issues which Short Loan could not address. There are different ways of course delivery methods these days, such as VLEs.

$\checkmark$ With the advancement of technology and various methods used to deliver course materials to patrons, copyright issues seem to have come up as a challenge.

$\checkmark$ What remains unaffected is the role of the librarians in an academic library as they have fresh roles to play with the advancement of technology. This new role gives the librarians an opportunity to be more innovative and add value to the information that is imparted to students. 


\section{Research Design}

\subsection{Methodology}

This study has used a mixed- methods approach using both qualitative and quantitative approach since it provides a better understanding to a problem. Klyuev, Tsuchimoto \& Nikishkov (2008) points out that "a questionnaire is a useful instrument to get users opinion on tools used by the subjects". On the other hand, unfortunately, in this kind of approach, response rate is not always high, as many respondents choose not to undertake the survey. Therefore, follow up emails are a requirement. A blend of multiple choice questions for quantitative analysis and open ended questions for qualitative analysis in survey questionnaire will be included in this study.

Quantitative methods were selected for this study as they provide quite a few advantages.

- Research is designed for findings that can be generalized to the whole population, consequently quantitative methods used in this study provided an objective assessment of the phenomenon studied.

- Cheaper to conduct and provides a higher degree of reliability when compared to qualitative methods.

Qualitative methods proved beneficial for this study for below reasons:

- Provided a better understanding of the service by using this approach

- Since the current research conducted is first of its kind, qualitative approach proved to be flexible and it enabled the survey participants to express their views in depth and at the same time, it will give the researcher a deeper understanding of the aspects.

Disadvantages of qualitative methods are:

- Due to the researcher's geographical distance, interviews could not be held with the survey participants.

- Interviews are an expensive tool for conducting a research, at the same time, they can be time consuming and labor intensive.

- It would not have been possible to generalize results, if responses were obtained through interviews. 
In spite of the disadvantages, this approach was included because of the useful attributes mentioned above. Multiple choice questions for quantitative and open ended questions for

qualitative approach were used in the questionnaire to ensure a better understanding and participation.

\subsection{Research questions}

This research investigates the impact of ECM's on the following aspects of academic library Short Loan services:

- Access

- Service delivery

- Staffing

\section{Research Questions}

$\checkmark$ How and to what extent the electronic course materials solved has issues/improved services e.g. space, budget, loan period, and increase/decrease in staff workload in print short loan collection?

$\checkmark$ How and to what extent has the implementation of electronic course materials made an impact on staff work in a short loan collection?

\subsection{Data Collection - Using an online questionnaire}

Data collection consisted of an online survey which was sent out to the librarians who work with ECM's via an email with the URL link. Survey research is a systematic attempt to collect appropriate information, mostly from individuals which describes and explains beliefs, values, attitudes and behaviour of selected group of people (Gray, Williamson, Karp \& Dalphin, 2007). The findings from the survey can help to take a broader view to a wider population. The survey questionnaire can include both qualitative and quantitative aspects and thus, are used as a data collection technique for the surveys (Pickard, 2007). 
There are various benefits of using an online questionnaire as it provides various benefits over traditional paper based questionnaires.

- Online questionnaires are cheaper to manage since there is no paper cost involved or other materials required for printing.

- Time is a big factor while doing a research, therefore, online surveys saves researcher's time, while at the same time, reaching out to various people with common characteristics in a short duration of time, despite being separated by great geographic distances (Taylor, 2000).

- There is a greater deal of flexibility in displaying the questions, for example: Graphs / charts can be used for precision, help instructions, controls that allow users to select only the required number of options (Sharp, Rogers, \& Preece, 2002), which leads to an improved quality and management of survey data. Also the user groups are used to communicating digitally.

Along with the benefits, there are several disadvantages of using online questionnaire as a research tool.

- Amount of control that the researcher can exercise is limited, unlike interviews;

Since the researcher is not present at the time of completing the survey, there is no opportunity for any clarification of vague aspects, which may result in vague results. Thus, the questionnaire must be easy to understand. In this study, clear instructions were provided to the participants on how to complete the survey, and simple questions were used in the questionnaire in order to avoid any ambiguity.

\subsection{Research Sample}

Although, the exact population for this study is unknown, the research sample was targeted and it only involved the population of librarians who dealt specifically with ECM's in New Zealand tertiary institutions and therefore, questionnaires were sent to only those librarians who researcher was aware of dealt with ECM's. Therefore, by following this method, it was ensured that the response attained by the participants was thoroughly reliable. The librarians who dealt with ECM's were contacted via email and were sent a Participant Information Sheet for the study along with the contact details of the researcher along with the survey link. The questionnaire was designed to ensure that it was easy to follow and complete. 


\section{Data analysis and interpretation}

\subsection{Response Rate}

29 invitations were sent out to librarians. 25 (87\%) Responses were received from the respondents. According to Sudman \& Blair (1998), the response rate for questionnaires may well fluctuate between $10-60 \%$ Therefore, the response rate that was collected for this study was regarded as satisfactory to carry out an acceptable and adequate analysis. The New Zealand tertiary institutions from which responses were received were The University of Auckland, Otago University, Auckland University of Technology, University of Canterbury, Lincoln University, University of Waikato and Victoria University of Wellington. These responses were found to be suitable for this study, given that each institution has an estimate of approximately 3-4 staff who works with ECM's.

Questionnaires were also sent to Massey University; since they do not have ECM's services at their end, they were not included in this study. Massey University only provides links to electronic journal articles for academic staff to place in their online courses.

Questionnaires were only sent to the seven tertiary universities in New Zealand due to lack of time. 


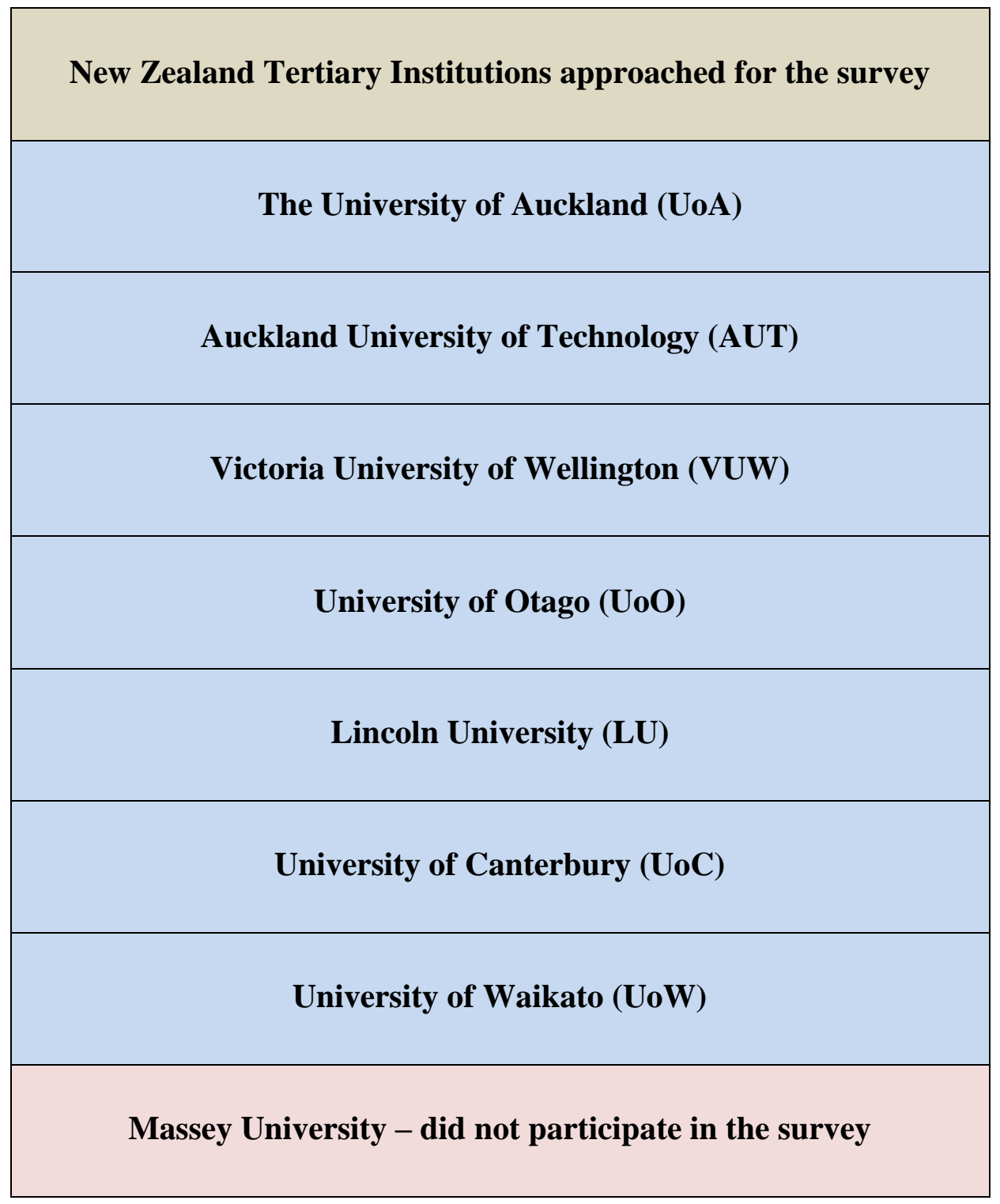

Table 2: New Zealand tertiary universities approached for the survey.

\subsection{Data Interpretation}

Librarians who worked with ECM's were surveyed at the seven tertiary institutions in New Zealand offering the service in an effort to understand how the ECM service affected staff work.

The objective of the survey primarily was to obtain how the ECM's service affected tertiary librarians' work and what new skills they had to learn, if at all, in order to perform their work satisfactorily. 


\subsubsection{How much of your work is with Electronic Course Materials?}

In the seven institutions surveyed:

- Thirteen (54\%) respondents replied that on an average 30\% of respondents spent their work time on ECM's

- Seven (29\%) respondents were involved with ECM's somewhere between 61-99\%

- Four (17\%) respondents involved with ECM's was somewhere between 31- 60\%.

\section{How much of your work is with Electronic Course Materials?}

\begin{tabular}{|l|l|l|l|l|}
\hline$\#$ & Answer & Response & $\%$ \\
\hline 1 & $30 \%$ & 13 & $54 \%$ \\
\hline 2 & $31-60 \%$ & 4 & $17 \%$ \\
\hline 3 & $61-99 \%$ & & 7 & $29 \%$ \\
\hline 4 & $100 \%$ & & 0 & $0 \%$ \\
\hline & Total & & 24 & $100 \%$ \\
\hline
\end{tabular}

Figure 1: Staff dealing with ECM's

\subsubsection{Working as a librarian with Electronic Course Materials requires in-depth training}

- $13(54 \%)$ respondents agreed to the fact that in order to work with ECM's, in-depth training is essential

- $4(17 \%)$ respondents disagreed that they needed any in-depth training to work with the ECM's

- $5(21 \%)$ respondents were neutral 
Working as a librarian with Electronic Course Materials requires in-depth training:

\begin{tabular}{|c|c|c|c|c|}
\hline & Answer & Response & $\%$ \\
\hline 1 & $\begin{array}{c}\text { Strongly } \\
\text { Disagree }\end{array}$ & & 0 & $0 \%$ \\
\hline 2 & Disagree & & 4 & $17 \%$ \\
\hline 3 & $\begin{array}{c}\text { Neither Agree } \\
\text { nor Disagree }\end{array}$ & & 5 & $21 \%$ \\
\hline 4 & Agree & & 13 & $54 \%$ \\
\hline 5 & $\begin{array}{c}\text { Strongly } \\
\text { Agree }\end{array}$ & & 2 & $8 \%$ \\
\hline & Total & 24 & $100 \%$ \\
\hline
\end{tabular}

Figure 2: Training required working with ECM's 


\subsubsection{Working with Electronic Course Materials requires learning new skills}

- $18(75 \%)$ respondents agreed to the fact that working with ECM's requires learning of new skills

- $5(21 \%)$ respondents strongly agreed that the learning of new skills are required

- $1(4 \%)$ respondent did not think that working with ECM's required learning new skills to perform the task.

\section{Working with Electronic Course Materials requires learning new skills:}

\begin{tabular}{|c|c|c|c|}
\hline$\#$ & Answer & Response & $\%$ \\
\hline 1 & $\begin{array}{l}\text { Strongly } \\
\text { Disagree }\end{array}$ & 0 & $0 \%$ \\
\hline 2 & Disagree & 1 & $4 \%$ \\
\hline 3 & $\begin{array}{l}\text { Neither } \\
\text { Agree nor } \\
\text { Disagree }\end{array}$ & 0 & $0 \%$ \\
\hline 4 & Agree & 18 & $75 \%$ \\
\hline 5 & $\begin{array}{c}\text { Strongly } \\
\text { Agree }\end{array}$ & 5 & $21 \%$ \\
\hline & Total & 24 & $100 \%$ \\
\hline
\end{tabular}

Figure 3: Learning New Skills 
6.2.4 What are the new skills that you had to learn in order to work with Electronic Course Materials in a satisfactory manner?

The respondents were asked to mark the skills learnt and replies are as follows:

- $16(67 \%)$ Scanning

- $11(46 \%)$ Image Manipulation

- 16 (67\%) PDF Processing

- $20(83 \%)$ Checking copyright status of items

- $17(71 \%)$ Cataloguing of digital materials

- $10(42 \%)$ Working with spreadsheets

- $6(25 \%)$ Working with databases

- $2(8 \%)$ Specified working with an online Content Management System. 
What are the new skills that you had to learn in order to work with Electronic Course Materials in a satisfactory manner?

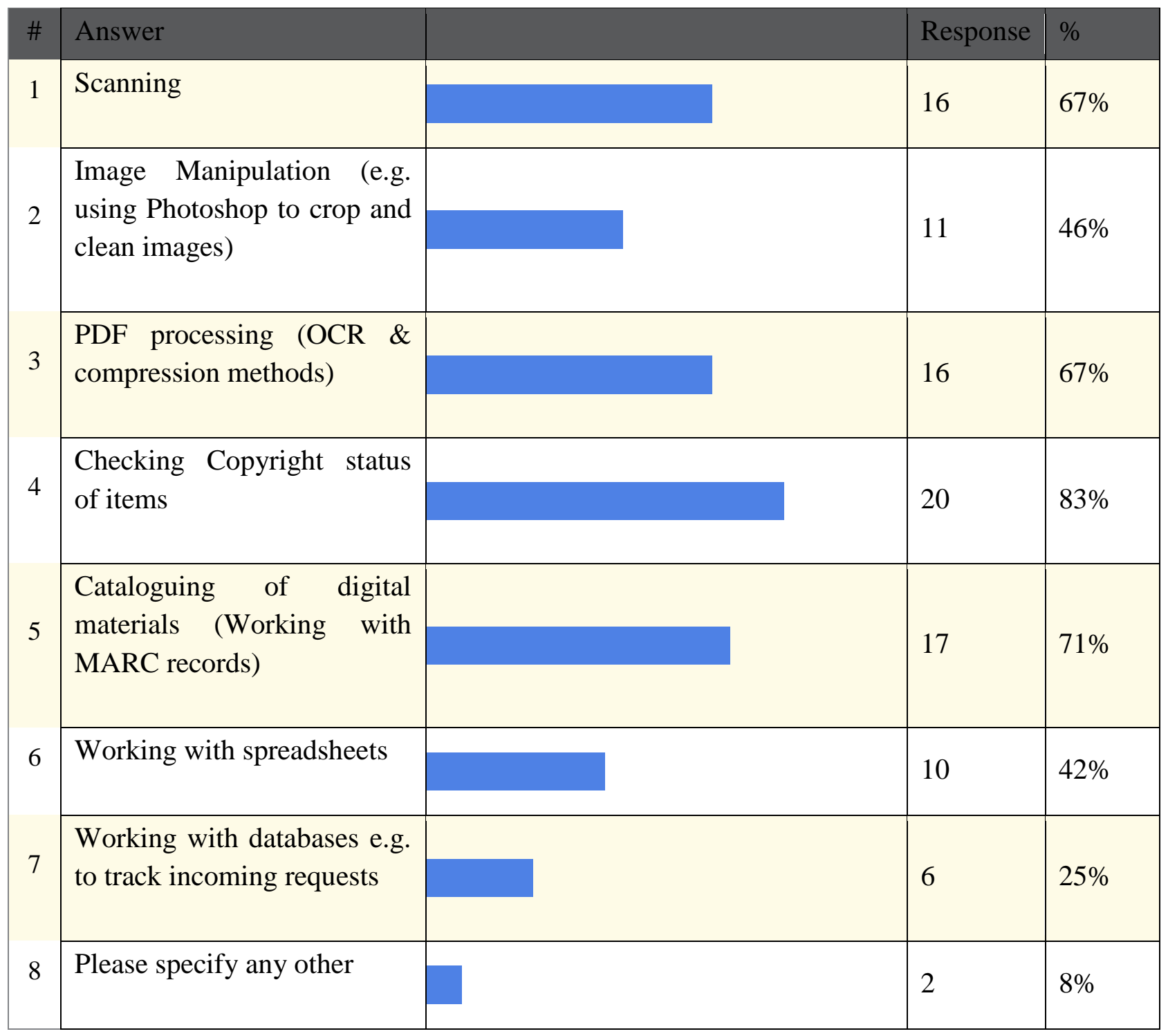

Figure 4: New skills which staff had to learn while working with ECM's 
6.2.5 What are you faced with most often when working with Electronic Course Materials? Please rank the following items, 1 being the most common issue, 6 being the least common issue.

Respondents were asked to comment on issues they faced often while working with ECM's.

- Copyright clearance - Majority of the staff responded that Copyright clearance is one of the most common issues librarians face while working with ECM's.

- Scanning quality of scanned items -8 respondents indicated that scanning quality if scanned materials is something they have to deal often with.

- Scanning quality of original items - Majority of respondents however indicated that scanning quality of original items was not an issue.

- Non availability of items - Majority of respondents indicated that non availability of items is something they are faced with on most occasions.

- Co-coordinating with other departments / other divisional libraries -Majority of respondents felt that coordinating with other departments or other divisional libraries was not an issue.

- Finding Bibliographic details - Majority of the respondents felt that finding bibliographic details was not an issue.

- Others -2 respondents indicated that requestors often did not check if materials that they are requesting are already digitized or not. 
What are you faced with most often when working with Electronic Course Materials?

Please rank the following items, 1 being the most common issue, 6 being the least common issue.

\begin{tabular}{|c|c|c|c|c|c|c|c|c|c|}
\hline$\#$ & Answer & 1 & 2 & 3 & 4 & 5 & 6 & 7 & $\begin{array}{l}\text { Response } \\
\mathrm{S}\end{array}$ \\
\hline 1 & Copyright Clearance & 9 & 5 & 1 & 2 & 2 & 1 & 1 & 21 \\
\hline 2 & $\begin{array}{l}\text { Scanning quality of } \\
\text { scanned items }\end{array}$ & 8 & 0 & 1 & 1 & 2 & 4 & 0 & 16 \\
\hline 3 & $\begin{array}{l}\text { Scanning quality of } \\
\text { original items }\end{array}$ & 0 & 3 & 5 & 6 & 3 & 3 & 0 & 20 \\
\hline 4 & $\begin{array}{l}\text { Non-availability of items } \\
\text { (i.e. missing print items, } \\
\text { missing pages etc) }\end{array}$ & 0 & 6 & 4 & 3 & 2 & 3 & 2 & 20 \\
\hline 5 & $\begin{array}{l}\text { Co-coordinating with other } \\
\text { departments /other } \\
\text { divisional libraries }\end{array}$ & 1 & 0 & 2 & 5 & 5 & 5 & 1 & 19 \\
\hline 6 & $\begin{array}{l}\text { Finding bibliographic } \\
\text { details of items }\end{array}$ & 1 & 2 & 4 & 4 & 7 & 1 & 1 & 20 \\
\hline 7 & Please specify any other & 0 & 0 & 1 & 0 & 0 & 0 & 0 & 2 \\
\hline & Total & 19 & 16 & 18 & 21 & 21 & 17 & 5 & - \\
\hline
\end{tabular}

Figure 5 Issues faced by staff while working with ECM's 
6.2.6 In the last 2 years instructors requests for readings for availability as Electronic Course Materials have increased over their demand for hard copy availability

Staffs were asked if they felt that in the last couple of years, requests for ECM's have increased over the demand for hard copy.

- $1(4 \%)$ disagreed

- $9(38 \%)$ were neutral on this point

- $6(25 \%)$ agreed

- $8(33 \%)$ strongly

In the last 2 years instructors requests for readings for availability as Electronic Course Materials have increased over their demand for hard copy availability

\begin{tabular}{|l|l|l|l|l|}
\hline$\#$ & Answer & & Response & $\%$ \\
\hline 1 & Strongly Disagree & & 0 & $0 \%$ \\
\hline 2 & Disagree & & 1 & $4 \%$ \\
\hline 3 & Neither Agree nor Disagree & & 9 & $38 \%$ \\
\hline 4 & Agree & & 6 & $25 \%$ \\
\hline 5 & Strongly Agree & & 8 & $33 \%$ \\
\hline & Total & & 24 & $100 \%$ \\
\hline
\end{tabular}

Figure 6: ECM's vs. print hard copy 
- $2(8 \%)$ Strongly disagreed

- $10(42 \%)$ Disagreed

- $3(13 \%)$ Were neutral on this point

- $6(25 \%)$ Agreed

- $3(13 \%)$ Strongly agreed.

\section{Working with Electronic Course Materials means I have less contact with students}

\begin{tabular}{|c|c|c|c|}
\hline$\#$ & Answer & Response & $\%$ \\
\hline 1 & Strongly Disagree & 2 & $8 \%$ \\
\hline 2 & Disagree & 10 & $42 \%$ \\
\hline 3 & $\begin{array}{l}\text { Neither Agree nor } \\
\text { Disagree }\end{array}$ & 3 & $13 \%$ \\
\hline 4 & Agree & 6 & $25 \%$ \\
\hline 5 & Strongly Agree & 3 & $13 \%$ \\
\hline & Total & 24 & $100 \%$ \\
\hline
\end{tabular}

Figure 7: Staff dealing with ECM's contact with students 
- $6(25 \%)$ Strongly agreed

- $12(50 \%)$ Disagreed

- $3(13 \%)$ Were neutral on this point

- 3 (135) Agreed

\section{Working with Electronic Course Materials means I have less contact with staff}

\begin{tabular}{|c|c|c|c|}
\hline \# & Answer & Response & $\%$ \\
\hline 1 & Strongly Disagree & 6 & $25 \%$ \\
\hline 2 & Disagree & 12 & $50 \%$ \\
\hline 3 & $\begin{array}{c}\text { Neither Agree nor } \\
\text { Disagree }\end{array}$ & 3 & $13 \%$ \\
\hline 4 & Agree & 3 & $13 \%$ \\
\hline 5 & Strongly Agree & 0 & $0 \%$ \\
\hline & Total & 24 & $100 \%$ \\
\hline
\end{tabular}

Figure 8: Staff dealing with ECM's contact with other staff 


\section{Results}

\subsection{Response rate}

Eight New Zealand universities were approached and only one, Massey University, did not reply (see figure 1) since they do not have an ECM's service. This was regarded as a more than satisfactory response rate to complete the study effectively considering each institution surveyed has 3-4 staff dedicated to ECM service. It was not possible to do a comparative study as no other similar study had been done before.

\subsection{How much of your work is with Electronic Course Materials?}

The responses can be interpreted as follows:

- The seven respondents involved with ECM's for $61-99 \%$ has ECM's as the core responsibility of their jobs

- The four respondents working on ECM's 31-60\% of their work time only assist with the ECM's when necessary

- The 13 respondents working an average of 30\% of their time on ECM's only assist during peak periods, i.e. the few weeks before and after semester starts.

\subsection{Working as a librarian with Electronic Course Materials requires in-depth training} The processing of ECM's is highly technical. It requires knowledge of:

- Scanning procedures - The selection of scanning input settings is an important part in the PDF production process. Obtaining the best quality scan reduces work that needs to be done later in post-production. Parameters that should be set include resolution, i.e. 300 or 600 dpi; original type, i.e. grayscale, black and white or color; scan size

- Photoshop for cropping and cleaning

- Optical Character Recognition (OCR) creates a searchable and editable text file based on the content of the scanned PDF. This renders greater functionality of the file to the end user. 
It is important to note that the majority of respondents conferred that training was either necessary. $13(54 \%)$ respondents agreed thought it was essential and $8 \%$ thought that it should be a pre-requisite. $4(17 \%)$ respondents disagreed that they needed any in-depth training to work with the ECM's, which can be interpreted that they had the required skills and approach to work satisfactorily with ECM's. 5 (21\%) respondents were neutral, which again can be interpreted that they were familiar with the technology, and had the required skills to perform the tasks in a satisfactory manner.

\subsection{Working with Electronic Course Materials requires learning new skills}

As stated above the processing of ECM's is highly technical. 23 (96\%) of respondents were in agreement that ECM's required learning new skills to guarantee efficiency. 1 (4\%) respondent did not think that working with ECM's required learning new skills to perform the task. It is not clear why the one respondent thinks ECM's does not require the learning of new skills considering the highly technical requirements for the processing of ECM's.

It can be stated with certainty that the learning of new skills is vital before the processing of ECM's can be taken on with confidence.

\subsection{What are the new skills that you had to learn in order to work with Electronic Course Materials in a satisfactory manner?}

From the responses received it is clear that checking that items comply with Copyright guidelines was the foremost skill (83\%) required. Every item requested as an ECM has to be checked whether it fulfills the guidelines as set by Copyright Licensing New Zealand (CLNZ). The CLNZ license allows tertiary institutions to share copies or digitised material with students from an original hardcopy. Learning cataloguing skills followed with $71 \%$. There are a number of cataloguing rules that the process has to abide with. Unless a librarian has grounded knowledge of cataloguing, it is an essential skill that has to be acquired. MARC rules are used if the records are saved on a server. Even if the records are saved differently, i.e. Digitool, cataloguing. Metadata is still used to create the record.

Scanning and PDF processing both had a $67 \%$ response rate. The importance of these two procedures is set out above.

$10(42 \%)$ respondents acquired knowledge of working with spreadsheets. Six (25\%) had to learn to work with a database. These six respondents were all from the University of Auckland. The University of Auckland Library has a sophisticated in-house created Course Materials Request Administration 
Database (CoMRAD) which tracks and records details of all requests for electronic and hard copy course materials.

Two respondents had to learn working with an online Content Management System.

7.6 What are you faced with most often when working with Electronic Course Materials? Please rank the following items, 1 being the most common issue, 6 being the least common issue.

The respondents ranked the items as follows:

- Copyright clearance - The researcher agrees with the response of the majority of respondents who saw Copyright clearance is one of the most common issues librarians face while working with ECM's. As explained above Copyright has to comply with the guidelines as set by CLNZ. It was intriguing to note that there was 1 respondent who did not see Copyright clearance as an issue; this could be interpreted that the academics might be doing this before submitting a request for an ECM. However, this is regarded as one of the principle tasks of the staff dealing with ECM's.

- Scanning quality of scanned items - Although this might be seen as a time consuming issue, it may result in delay in the processing ECM requests if the quality is not up to standard.

- Scanning quality of original items - Scanning quality of original items was not regarded as an issue. This could be because original items consist of books and journals, where the quality of print is generally good, although there may be books located in libraries that may have underlines and highlighter marks made by students in some cases.

- Non availability of items - Respondents indicated that non availability of items is something they are faced with on often. This could be so, since the items are generally located at a library, there may be just one copy of the required copy or students may have the items issued out to themselves, in this case a staff will have to place a recall resulting in delay which again depends when the student returns the item. Another possibility may be that items may be misplaced/lost from the shelves or relevant pages may be missing from the items. Another factor could be that the particular item is not held at the library at 
all, in which case the item has to be ordered for the library under section 54 of the Copyright Act and Amendments.

- Co-coordinating with other departments / other divisional libraries -Majority of respondents did not consider coordinating with other departments or other divisional libraries an issue. This may be seen as a positive sign, as staff at divisional libraries may see ECM's as an urgent task that needs to be dealt immediately, since students are involved. Or relationships between the different departments and divisional libraries may be of a high standard.

- Finding Bibliographic details - Most respondents felt that finding bibliographic details was not an issue as most staff at libraries is familiar with databases and other scholarly online searching techniques as responded by the participants during the survey.

- Others - The response from 2 respondents that requestors often did not check if materials they are requesting are already digitized or not can be an issue which results in duplication of work, waste of staff time and may also in some cases result in breach of the Copyright Act.

\subsection{In the last 2 years instructors requests for readings for availability as Electronic Course Materials have increased over their demand for hard copy availability}

The results are fairly ambiguous and vague, and a definite conclusion could not be reached. The researcher can only offer the possibility that it is due to academics unawareness for this particular service. However, in a research conducted exclusively for The University of Auckland, by Upeksha Amarathunga (2009), it was revealed that:

$\checkmark$ There is a connection between the academic staff awareness and the staff uptake of the service.

$\checkmark$ Subject librarians play an important role in promoting the ECM service in academic departments in academic libraries.

$\checkmark$ Most common way of providing the access to course materials was through WebCT and other VLE's system. 
$\checkmark$ Library's ECM webpage was less significant as far as promoting of ECM's was concerned.

$\checkmark$ Only $50 \%$ of the staff members who were aware of the ECM service availed the service to digitise course materials. 


\section{Conclusions / Recommendations}

As per the study, the institutions surveyed have made considerable alterations to their operations where one third of the respondents spend majority of their time with ECM's, although the institutions continue to offer a traditional service i.e. offering the provision of physical items. The ECM's service has been added to enhance the service offered to its users. It was interesting to note that Massey University does not have an ECM's service. They only provide links to electronic journal articles for academic staff to place in their online courses. Hence, this particular institution was not included in this study.

\subsection{Recommendations}

One of the questions this study sought to answer was if ECM's have made any impact, if at all, on staff's work. The result of the survey indicates that ECM's caused a significant change in staff workflow. Rather than staff spending their time in processing hard copy items, mending or replacing missing pages, lost or damaged books, they now spend a good amount of their time in performing tasks that require a fair amount of technological expertise, for example, scanning, working on Photoshop to edit images or verifying web links. Through the researcher's personal experience, staff does have a heavy workload to deal with before and at the beginning of each semester, working on Copyright clearance is a new task that the staff has to learn to work with and this requires a good amount of time commitment and attention to detail.

For more than a decade, libraries have provided reserves as ways to meet the information demand and needs of faculty and students alike. It will be interesting to see which direction the ECM's service goes to in the next 10 years. However, due to its popularity amongst the users, academic staff and students alike, the ECM's service signifies that it will continue to develop in the future. Without any doubt technological advancements will change the approach and form in which ECM's are represented and made accessible to its users. 
Below are the recommendations:

$\checkmark$ Time must be set aside and programmes created to train staff sufficiently for the ECM's task

$\checkmark$ It is imperative that basic structure which includes equipments, staffing, software upgrades and staff training has to be mainstreamed into a library's strategic planning and budgeting process for institutions where it is not being done so yet.

$\checkmark$ Creation of an alliance within the library, with teaching faculties and instructors, and with other support units available on campus will help in highlighting the ever growing demand for such services and the impact they have made on the educational mission of an institution.

$\checkmark$ Requestors often do not check if materials they are requesting are already digitized or not. This results in duplication of work, waste of staff time and may also in some cases result in breach of the Copyright Act. This issue can be addressed by requesting academics or library staff to check for pre-existing items before placing a request. This will not only save their time but will also save that particular staff time processing the ECM.

$\checkmark$ Libraries without an online request submission application, such as the CoMRAD application used at the University of Auckland, should consider creating in-house or buying into such an application as it will ease the receiving and tracking of requests. Talis Aspire Campus Edition has an excellent tool available worldwide. Talis Aspire is a cloud-based, reading-list application that enables universities to transform resource discovery and nonstop access for learners - online and mobile. Since its launch in 2009, Talis Aspire Campus Edition has become the benchmark for reading-list management in the UK. Talis Aspire Campus Edition is available to all universities and colleges, and is delivered safely and securely - from the cloud. With Talis Aspire Campus Edition lecturers and librarians create reading-lists using simple drag ' $n$ ' drop tools. Library linking, acquisitions alerting and resource location functions make it easy for learners to connect with the library and find what they want - online, and for a continuous access. 
In conclusion, the development opportunities presented to staff by ECM's to learn new skills, broaden their horizons and gain knowledge, are to their advantage. In various ways, they are performing more intricate duties than before. Although the major benefits of ECM's lie in its customer service aspects, library staff has also gained by the onset of the ECM's service. 


\section{References}

Amarathunga, U. S. (2008). "Factors affecting staff demand for an electronic course materials service". Retrieved from: http://researcharchive.vuw.ac.nz/bitstream/handle/10063/1286/thesis.pdf?sequence=1

Austin, B. (2004). Reserves, electronic reserves, and copyright: the past and the future. Binghamton, NY: Haworth Press.

Austin (2008). A Brief History of Electronic Reserves. Journal of Interlibrary Loan, Document Delivery \& Information Supply, vol.12 (2), 2001

Banerjee, N. (2011). Preliminary Literature Review. INFO 528: Research methods. Auckland, Victoria University of Wellington: 1-5.

Becta (2004). What the research says about Virtual Learning Environments in teaching and Learning. Website: https://www.education.gov.uk/publications/eOrderingDownload/15003.pdf

Berg, S. A., Hoffman, K. \& Dawson D (2010). "Not on the same page: undergraduate's retrieval in electronic and print books." Journal of Academic Librarianship 36(6): 518-525.

Bridges, A. (2007). "E-reserves threatened at Cornell." C \& RL News 68(5): 317.

Butler, B (1993). "Electronic Course Reserves and Digital Libraries: Progenitor and Prognosis." Journal of Academic Librarianship 22(2) 124-127

Cockrill, A. (1997). Coping with change: issues facing British and German university libraries in the 1990s. Journal of Librarianship and Information Science, 29(2) 77-88.

Copyright Licensing New Zealand. Retrieved on September 20, 2012, from

http://www.copyright.co.nz/Educational/ 
Creth, S. D. (1996). "The electronic library: slouching toward the future or creating a new information environment?" Follett Lecture Series from:

http://www.ukoln.ac.uk/services/papers/follett/creth/paper.html

D.L. Goodhue \& R.L. Thompson.(1995). Task-technology fit and individual performance. MIS Quarterly 19(2), 213-236.

Davies, J.E. (1997) Learn by wire: managing network access to learning materials. The Electronic Library. 15, (3), $205-214$

Dugdale, C. (1997). Information spoon-feeding in an electronic environment. Electronic Publishing '97 New Models and Opportunities: Proceedings of an ICCC/IFIP conference held at the University of Kent, Canterbury, UK, April 14-16 1997, Retreived from: http://elpub.scix.net/data/works/att/97111.content.pdf

Dugdale, C. (1999).Managing electronic reserves : new opportunities and new roles for academic librarians ? Librarian career development 7(12): 150-163.

Dugdale, C. (1999). Academic/librarianship partnerships in the electronic library. Program, 33 (1) p. 1528

Dugdale, C. (1999). The role of electronic reserves on serving and shaping new teaching and learning environments in UK universities. Journal of information science, 25 (3) 183-192

Driscoll, L (2003). The how to do it manual of electronic reserve, Journal of Interlibrary Loan, 14(1).

Edwards, H (2006), Electronic Reserves: making it happen. Journal of Interlibrary Loan, Document Delivery \& Electronic Reserves. 6(4) 31-36.

Feather, J. \& M.R. (1993). Unchartered territory: academic libraries and the growth in the student numbers. Library review 42(3): 20-30. 
Ferullo, D. L. (2002). The challenge of e-reserves: Donna L. Ferullo explains how copyright law is an asset in creating e-reserve programs. School library journal, 127(1) 33-35.

Goodson, K.A. \& Fredericksen, L. (2011). E-reserves in transition: exploring new possibilities in e-reserves service delivery; Journal of Interlibrary Loan, Document Delivery \& Electronic Reserve, 21(1):33-56).

Gray, P.S., Williamson, J.B., Karp, D.A., \& Dalphin, J.R. (2007). The Research Imagination: An Introduction to Qualitative and Quantitative Methods. Cambridge, USA: Cambridge, University Press.

Groenewegen, H. W. (1998). "Electronic reserves: key issues and innovations. Australian Academic and research libraries. 29(1).

Handy, C. (1994). The empty raincoat. London: Hutchinson

Hoppenfeld, J \& Wendi Arant-Kaspar (2010). Do it yourself for course reserves: A student driven service in an academic library; Journal of Interlibrary Loan, Document Delivery \& Electronic Reserve, 20 (5) 353-361.

Hammersley, M. (n.d.). An outline of methodological approaches. Retrieved June 19, 2012, from http://www.tlrp.org/capacity/rm/wt/hammersley/hammersley4.html

Jackson, M., Gider, A, Feather, C (et al) (2007). Electronic Resources \& Libraries, 2nd Annual Conference 2007.

Jacobsen, D. M. K., R (2000). Online testing and grading using WebCT in computer science. Paper presented at WebNet 2000: World conference on the WWW and the Internet, San Antonio, Texas, 30 October - 4 November.

Juceviciene, P. and Tautkeviciene, G, 2003. Academic library as a learning environment: how do students perceive it? Retrieved June 18, 2012, from

http://www.leeds.ac.uk/educol/documents/00003274.htm

Klyuev, V, Tsuchimoto, T. \& Nikishkov, G.P. (2008). Using a web-based system to support teaching processes. International Journal of Information and Communication Technology Education, 4(1), 72-86 
Konicek, K., Hyzny, J and Allegra, Richard (2003). Electronic Reserves: the promise and challenge to increase accessibility. Library Hi tech 21(1): 102-108.

Kovacs, D. K. (1999). Electronic publishing in libraries: introduction. Library Hi tech 17(1): 8-9.

Kristof, C. (1999). Electronic Reserves Operations in ARL Libraries. Spec Flyer 245

Kupersmith, J. (2010). John Kupersmith's webspace. Retrieved on $18^{\text {th }}$ June, 2012 from http://www.jkup.net/

Laskowski, M. S \& Ward, (2003).The impact of implementing electronic reserves on staffing and service; Journal of Interlibrary loan, document delivery \& information supply. 13(3) 15-28

Lin, T. \& Huang, C.(2008). Understanding knowledge management system usage antecedents: an integration of social cognitive theory and task technology fit. Information and management, $45,410-417$.

Macdonald, D., Kirk, D., Metzler, et al. (2002). It's all very well, in theory: Theoretical perspectives and their applications in contemporary pedagogical research. QUEST, 54, 133-156.

Mackenzie,N.\& Knipe, S. (2006) Research dilemmas: Paradigms, methods and methodology. Issues in Educational Research, 16(2), 193-205. Retrieved August 9, 2009, from http://www.iier.org.au/iier16/mackenzie.html

Magusin, E \& Johnson, K (2004): Collaborating on electronic course reserves to support student success, Journal of Library Administration. 41(1-2) 255-264

McCaslin. D.J (2008). Processing electronic reserves in a large academic library system, Journal of Interlibrary Loan, Document delivery \& electronic reserve. 18(3) 335-346

Melamut, S (2000). "Pursuing Fair Use, Law Libraries, and Electronic Reserves." Law Library Journal, 92(2) 157-192.

Moyo, L.M. (2004).Electronic libraries and the emergence of new service paradigms; The Electronic Library, 22 (3) 220-230 
Pearce, L. (2003). The development of electronic reserves at the University of Calgary. Retrieved $20^{\text {th }}$ July, 2012 from http://www.dlib.org/dlib/november01/pearce/11pearce.html.

Pickard, A. J. (2007). Research Methods in Information. London, UK: Facet.

Rice-Lively, M. L. \& R., J.D. (1997). The role of academic librarians in the era of information technology. Journal of Academic Librarianship 23(1) 31-41.

Rojeski, M, (2012). User perceptions of eBooks versus print books for class reserves in an academic library; Reference services review, 40(2) 228-241

Rosedale, J. (2002). Managing Electronic Reserves. Chicago, Chicago, American library association.

Rowlinson, C. (2000). Supporting learning through on-demand and electronic reserve services." Collection Building 19(2) 56-60.

Seaman, S. (1996). Copyright and fair use in an electronic reserves system. Journal of Interlibrary Loan, Document Delivery \& Information Supply, 7(2), 19-29.

Secker, J. (2001). Access to core course materials project: final report. Retrieved July 12, 2012 from University College London Web site: http://www.ucl.ac.uk/calt/tqef/core/final.pdf

Sharp, H., Rogers, Y., \& Preece, J. (2002). Interaction Design: Beyond Human-Computer Interaction. John Wiley \& Sons.

Shapiro, B. (1995) Design issues in planning electronic reserves. The Electronic Library, 13(3), 219-221.

Sumsion, J. (1994) Survey of resources and uses in higher education libraries: UK, 1993. Library and Information Statistics Unit, Loughborough University of Technology, occasional Paper No 6.) Loughborough University.

Sumsion, J. (1997). University libraries under the microscope. Bookseller, 24 January, 20-22

Tabs, E. D. (2003). Academic Libraries: 2000. Retrieved from: http://nces.ed.gov/pubs2004/2004317.pdf.

Taylor, H. (2000). Does Internet research work? Comparing electronic survey results with telephone survey. International Journal of Market Research, 42 (1), 51-63.

Talis Aspire Website: http://campus.talisaspire.com/ 
University of Auckland (2011). Kate Edger Information Commons Short Loan. Retrieved October 14, 2011, from the University of Auckland Library Web site: http://www.library.auckland.ac.nz/slc/ 


\section{Appendices}

\section{Appendix 1: Cover letter of the questionnaire}

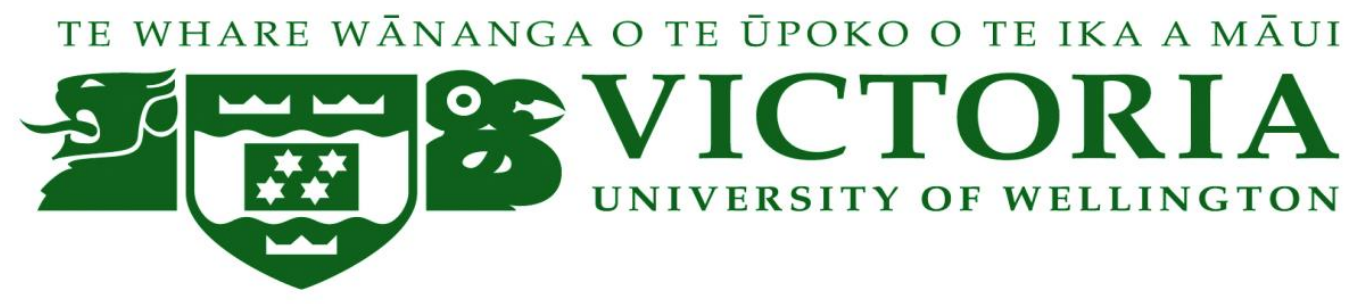

Participant Information Sheet for Study on impact of Electronic Course Materials on Short Loan Collection Libraries in New Zealand.

Researcher: Namrata Banerjee - School of Information Management, Victoria University of Wellington

I am a Master of Information Studies (MIS) student at Victoria University of Wellington. As part of this degree, I am undertaking a research project, the report of which will be deposited in the Victoria University of Wellington Library and Institutional Repository. I am surveying Librarians who deal with Electronic Course Materials in a Short Loan Collections in New Zealand tertiary libraries.

This survey will determine the impact Electronic Course Materials have on the work of Short Loan collection librarians. The project title is Impact of Electronic Course Materials on Short Loan Libraries.

The Victoria University of Wellington requires that ethics approval be obtained for research involving human participants. The link to the online questionnaire is provided at the bottom of the sheet. It is envisaged that the questionnaire will take about 10 minutes to complete. 
Participants can withdraw from the survey at any time, until they submit the survey by closing the browser. However, kindly note, participants will not be able to withdraw from the survey once they have submitted the survey since their data will be anonymous. Submitting the survey will be regarded as consenting to participation.

The IP address of the participants and their details will not be captured by the on-line survey system to assure participants of anonymity. Responses collected will form the foundation of my research project and responses will be put into a written report on an anonymous basis. It will not be possible to identify the participants personally. All materials collected will be password protected and will be kept confidential. No other person besides me and my supervisor, Alastair Smith, will see the completed questionnaires. The report will be submitted for marking to the School of Information Management and deposited in the University's online research archive. It is intended that one or more articles will be submitted for publication in journals and conferences. The data will be destroyed two years after the end of the project.

I invite you to send me an email (banerjnamr@myvuw.ac.nz) if you would like a summary of the results. One follow-up reminder will be sent 7 days after sending the questionnaire.

If you have any questions or would like to receive further information about the project, please contact me or my supervisor.

\section{Contact details}

The researcher of the project, Namrata Banerjee, Master of Information Studies (MIS) student contact details: banerjnamr@myvuw.ac.nz

The supervisor of the project, Alastair Smith, Senior Lecturer of the School of Information Management, Victoria University of Wellington.

Contact: Alastair.Smith@ vuw.ac.nz Ph: Ph 6444635785 
Please click on the link to complete the Survey:

http://vuw.qualtrics.com/SE/?SID=SV_0iDr3K1h3hupAtT 


\title{
Appendix 2: Email to the managers for survey participation
}

\author{
Email for Managers to forward the survey to the respondents
}

I am a Master of Information Studies (MIS) student at Victoria University of Wellington. As part of this degree, I am undertaking a research project, I am surveying Librarians who deal with Electronic Course Materials service in a Short Loan collection in New Zealand tertiary libraries.

It will be helpful, if you could kindly forward the link to the survey to the librarians who work with Electronic Course Materials (ECM) service at your library.

If you or the respondents have any questions before completing the survey, please do not hesitate to contact me at: banerjnamr@myvuw.ac.nz

I assure you that all survey responses provided for the study will be completely confidential.

Thank you

Namrata Banerjee

Master of Information Studies (MIS)

Victoria University of Wellington 


\section{Appendix 3: Questionnaire}

How much of your work is with Electronic Course Materials?
$30 \%$
$31-60 \%$
$61-99 \%$
$100 \%$

Working as a librarian with Electronic Course Materials requires in-depth training:

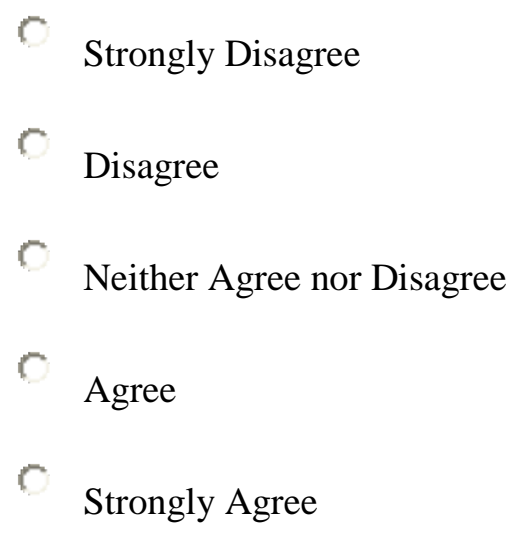

Working with Electronic Course Materials requires learning new skills:
Strongly Disagree
Disagree
Neither Agree nor Disagree
Agree
Strongly Agree

Namrata Banerjee

30020084 
What are the new skills that you had to learn in order to work with Electronic Course Materials in a satisfactory manner?

Scanning

Image Manipulation (e.g. using Photoshop to crop and clean images)

$\Gamma$

PDF processing (OCR \& compression methods)

$\Gamma$

Checking Copyright status of items

$\Gamma$ Cataloguing of digital materials (Working with MARC records)

$\Gamma$ Working with spreadsheets

$\Gamma$ Working with databases e.g. to track incoming requests

$\Gamma$ Please specify any other

What are you faced with most often when working with Electronic Course Materials? Please rank the following items, 1 being the most common issue, 6 being the least common issue.

\begin{tabular}{|c|c|c|c|c|c|c|c|}
\hline & 1 & 2 & 3 & 4 & 5 & 6 & 7 \\
\hline Copyright Clearance & $r$ & $r$ & 6 & r & $r$ & $r$ & $\mathrm{C}$ \\
\hline Scanning quality of scanned items & $r$ & $C$ & 6 & C & r & $C$ & $\mathrm{C}$ \\
\hline Scanning quality of original items & $r$ & $C$ & 6 & $\mathrm{C}$ & r & $C$ & $\mathrm{C}$ \\
\hline Non-availability of items (i.e. missing print items, missing pages etc) & $\mathrm{C}$ & $\mathrm{C}$ & 6 & $\mathrm{C}$ & $r$ & $\mathrm{C}$ & $\bar{r}$ \\
\hline Co-coordinating with other departments /other divisional libraries & $\mathrm{C}$ & C & 6 & r & r & $C$ & $\mathrm{C}$ \\
\hline Finding bibliographic details of items & $\mathrm{C}$ & r & 6 & r & r & $C$ & $\mathrm{C}$ \\
\hline specify & $r$ & ro & C & Co & C & $C$ & $C$ \\
\hline
\end{tabular}




\begin{tabular}{|l|l|l|l|l|l|l|l|}
\hline \multicolumn{1}{|c|}{1} & 2 & 3 & 4 & 5 & 6 & 7 \\
\hline \hline & & & & & & & \\
\hline
\end{tabular}

In the last 2 years instructors requests for readings for availability as Electronic Course Materials have increased over their demand for hard copy availability:

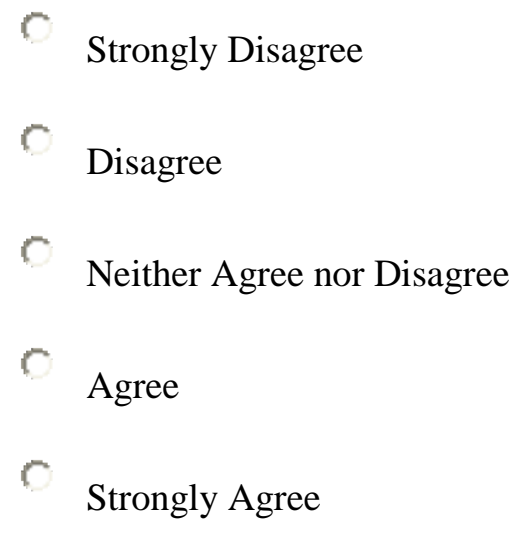

Working with Electronic Course Materials means I have less contact with students:

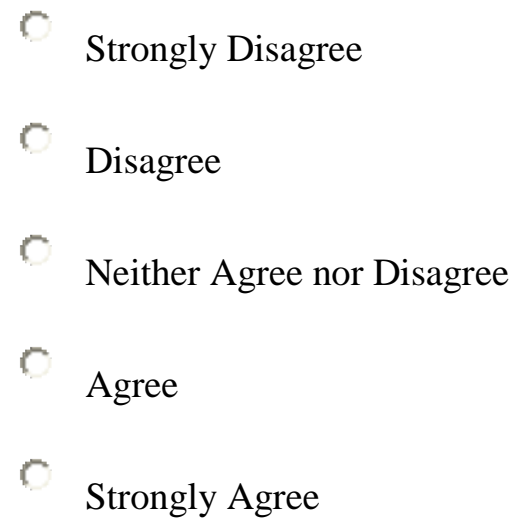

Working with Electronic Course Materials means I have less contact with staff:

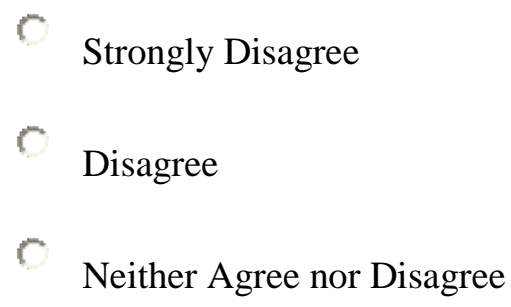


Agree

Strongly Agree

\section{Appendix 4: Reminder email}

\section{Hello All,}

Please pass on my thanks to your staff for their prompt responses to my survey. If, by any chance, any of your staff haven't had a chance to fill in the survey, it's not too late. They still have another week to do so.

Thank you very much for your kind assistance.

Namrata Banerjee

Master of Information Studies (MIS)

Victoria University of Wellington 
Namrata Banerjee

Word Count - 10,193

Namrata Banerjee

30020084 